\title{
Risk of cervical intraepithelial neoplasia in women with glomerulonephritis
}

\author{
F Hartveit, B Bertelsen, S Thunold, B O Mæhle, E Skaarland, J Christensen
}

\begin{abstract}
Objective-To investigate the occurrence of cervical intraepithelial neoplasia in women with glomerulonephritis and its possible association with immunosuppressive treatment.

Design-Retrospective study of cytological or histological specimens from women presenting with glomerulonephritis and a group of case and age matched controls.

Setting-University department of pathology, Norway.
\end{abstract}

Patients-81 women presenting with glomerulonephritis from 1981 to 1988 , from whom gynaecological cytological or histological specimens were available. A group of 162 case and age matched controls.

Main outcome measures-Age when glomerulonephritis of cervical intraepithelial neoplasia was diagnosed, type and characteristics of kidney lesion, stage of cervical intraepithelial neoplasia and presence of human papillomavirus, use of immunosuppressive treatment.

Results-Cervical intraepithelial neoplasia was more common in women with glomerulonephritis than in their controls (16/81 (20\%) $v 7 / 162(4 \%)$, $\mathbf{p}<0.001)$ and was more advanced in those with glomerulonephritis than in the controls $(9 / 81(11 \%)$ of the study group had grade III cervical intraepithelial neoplasia compared with $1 / 162(1 \%)$ of the controls). The increased occurrence of cervical lesions was independent of the use of immunosuppressive treatment, but the individual lesions tended to be more advanced when it was used (four of the seven cervical lesions in women with glomerulonephritis who had received immunosuppressive treatment were carcinoma in situ). Of the nine cervical lesions tested, seven were virus associated.

Conclusion-Women with glomerulonephritis should have regular cervical smears, irrespective of their use of immunosuppressive treatment.

F Hartveit, DRMED, professor B Bertelsen, CAND MED,

registrar

$S$ Thunold, DRMED, professor

B O Mæhle, DRMED, senior

lecturer

E Skaarland, DRMED, professor

J Christensen, DRMED, professor

(Professor Christensen died in 1989)

Correspondence to: Professor F Hartveit, Department of Pathology, Haukeland Hospital, 5021 Bergen, Norway.

BMF 1991;302:375-7 cervical intraepithelial neoplasia is thus well reported and generally accepted.
Our attention was drawn to a small group of women with glomerulonephritis and cervical intraepithelial neoplasia, not all of whom had received immunosuppressive treatment. We studied a series of women with glomerulonephritis, from whom cervical cytological or histological specimens were also available, to investigate the possibility of a primary relation between glomerulonephritis and cervical intraepithelial neoplasia, independent of immunosuppressive treatment.

\section{Methods}

Our department serves the county of Hordaland and its surrounding area, receiving roughly 40000 gynaecological cytological specimens and 23000 surgical biopsy specimens each year. Over the study period $(1981-8)$ glomerulonephritis was diagnosed in biopsy specimens from 81 women, from whom routine gynaecological cytological or histological specimens (or both) were also available. These women formed our study group. They were born from 1921 to 1970 .

We established a case and age matched control group of 162 women. For each case we found the next two women born in the same year from whom a routine gynaecological cytological specimen had been received at the same time as the corresponding first specimen for the index case. For the youngest woman, who was born in 1970, there was an age difference of three and four years between her and her controls; for one woman, born in 1921, there was an age difference of five years with one of the controls. Otherwise, both controls were born in the same year as their index case. None of the controls had glomerulonephritis or any other lesion associated with immunosuppressive treatment.

We recorded the age of the woman when glomerulonephritis was diagnosed. The kidney biopsy specimens were reviewed. The type of kidney lesion and its immunological characteristics were recorded. These had been investigated at primary diagnosis either by immunofluorescence techniques on frozen sections or in later cases using a standard peroxidaseantiperoxidase technique on formalin fixed material. We also recorded the use of immunosuppressive treatment, its type, duration, and the reason for its prescription.

We recorded the woman's age when cervical intraepithelial neoplasia was first diagnosed. All cytological or histological specimens from these women were reviewed for the presence or absence of koilocytosis. ${ }^{11}$ When sufficient material was available these specimens were also tested for human papillomavirus types $6 / 11$, $16 / 18$, and $31 / 33 / 35$ by in situ hybridisation using human papillomavirus tissue hybridisation kits (Gibco/BRL, Gaithersburg, Maryland).

Statistical methods used were Student's $t$ test and the $\chi^{2}$ test with Yates's correction when appropriate. 


\section{Results}

Renal lesions-The types of glomerular lesions recorded in the 81 women in the study group are shown in table I. Cervical intraepithelial neoplasia had been found in 16 of them. Mesangioproliferative lesions predominated, irrespective of the presence or absence of cervical intraepithelial neoplasia. The difference in the number of other types of lesions relative to the mesangioproliferative type between the two groups was not significant $\left(\chi^{2}=0 \cdot 8\right)$.

Cervical lesions - There were more cases of cervical intraepithelial neoplasia in the study group: 16/81 $(20 \%)$ of the women had cervical intraepithelial neoplasia in the study group compared with $7 / 162(4 \%)$ of the control group (table II). This fivefold difference was significant $\left(\chi^{2}=13, \mathrm{p}<0.001\right)$. There were more severe lesions in the study group than in the control group (table III). The total numbers were low, but there was only one woman with grade III disease among the 162 controls (1\%) compared with nine $(11 \%)$ in the study group-that is, an 18 -fold difference.

Immunosuppressive treatment - Table IV shows that immunosuppressive treatment had been given to 19 $(23 \%)$ of the 81 women with glomerulonephritis. In five of them cervical intraepithelial neoplasia was subsequently diagnosed. Cervical intraepithelial neoplasia was also diagnosed in 9 of the $62(15 \%)$ who had not received immunosuppressive treatment. This difference was not significant $\left(\chi^{2}=0 \cdot 7, \mathrm{p}<0 \cdot 2\right)$. Table V shows that the indications for immunosuppression were similar in women who had cervical intraepithelial neoplasia and those who had not.

Comparison with case matched controls - The number of women (5/19) developing cervical intraepithelial neoplasia after immunosuppressive treatment is too low for valid comparison with their case matched

TABLE I-Types of glomerular lesion recorded in 81 women in study group

\begin{tabular}{lcc}
\hline & \multicolumn{2}{c}{ No of women } \\
\cline { 2 - 3 } $\begin{array}{l}\text { Type of } \\
\text { glomerulonephritis }\end{array}$ & $\begin{array}{c}\text { With cervical } \\
\text { intraepithelial neoplasia }\end{array}$ & $\begin{array}{c}\text { Without cervical } \\
\text { intraepithelial neoplasia }\end{array}$ \\
\hline Mesangioproliferative & 10 & 48 \\
Membranoproliferative & 3 & 6 \\
Perimembranous & 1 & 1 \\
Endocapillary & 1 & 1 \\
Minimal proliferative & 1 & 6 \\
Minimal change & 16 & 3 \\
\hline Total & & 65 \\
\hline
\end{tabular}

TABLE II -Number of women with glomerulonephritis showing cervical intraepithelial neoplasia compared with controls

\begin{tabular}{lccr}
\hline & \multicolumn{3}{c}{ No of women } \\
\cline { 2 - 4 } & $\begin{array}{c}\text { Without cervical } \\
\text { intraepithelial } \\
\text { neoplasia }\end{array}$ & $\begin{array}{c}\text { With cervical } \\
\text { intraepithelial } \\
\text { neoplasia }\end{array}$ & Total \\
\hline Women & 65 & 16 & 81 \\
With glomerulonephritis & 155 & 7 & 162 \\
\hline Controls & 220 & 23 & 243 \\
\hline Total & & &
\end{tabular}

TABLE III-Degree of cervical intraepithelial neoplasia in women in study group compared with that in controls

\begin{tabular}{lcc}
\hline & \multicolumn{2}{c}{ No of women } \\
\cline { 2 - 3 } $\begin{array}{l}\text { Degree of cervical } \\
\text { intraepithelial neoplasia }\end{array}$ & Study group & Controls \\
\hline Mild dysplasia (grade I) & 7 & 6 \\
Grade III & 9 & 1 \\
$\quad$ Severe dysplasia & 3 & 1 \\
$\quad$ Cancer in situ & 6 & 7 \\
\hline Total with cervical intraepithelial & & 162 \\
$\quad$ neoplasia & 16 & \\
Total No of cases & 81 & \\
\hline
\end{tabular}

TABLE IV - Number of women with glomerulonephritis who developed cervical intraepithelial neoplasia after immunosuppressive treatment compared with those who did not have this treatment

\begin{tabular}{lccc}
\hline & \multicolumn{3}{c}{ No of women } \\
\cline { 2 - 4 } Women & $\begin{array}{c}\text { Without cervical } \\
\text { intraepithelial neoplasia }\end{array}$ & $\begin{array}{c}\text { With cervical } \\
\text { intraepithelial neoplasia }\end{array}$ & All \\
\hline Treated & 14 & 5 & 19 \\
Untreated & 53 & 9 & 62 \\
\hline Total & 67 & 14 & 81 \\
\hline
\end{tabular}

TABLE $\mathrm{v}$-Indications for immunosuppressive treatment in women in study group

\begin{tabular}{lccc}
\hline & \multicolumn{3}{c}{ No of women } \\
\cline { 2 - 4 } & $\begin{array}{c}\text { With cervical } \\
\text { intraepithelial } \\
\text { neoplasia }\end{array}$ & $\begin{array}{c}\text { Without cervical } \\
\text { intraepithelial } \\
\text { neoplasia }\end{array}$ & Total \\
\hline Indication & 4 & 5 & 9 \\
Systemic lupus erythematosus & 2 & 5 & 7 \\
Glomerulonephritis & 1 & 2 & 1 \\
Kidney transplantation & 7 & 12 & 19 \\
Other & & &
\end{tabular}

controls $(1 / 38)$ (table VI). Using all of the 162 controls for comparison the difference is highly significant $(5 / 19$ $v 7 / 162 ; \chi^{2}=9.9$ using Yates's correction, $\mathrm{p}<0.005$ ). The difference in the number of women with and without cervical intraepithelial neoplasia in the group of untreated women with glomerulonephritis when compared with their own controls was also significant $(9 / 62$ and $6 / 124$ for women with cervical intraepithelial neoplasia; 53/62 and 118/124 for those without cervical intraepithelial neoplasia; $\chi^{2}=3.9$ with Yates's correction), rising to 5.6 when all controls were used $(\mathrm{p}<0.02)$.

Viral infection-Samples of tissue from the cervical lesion were available for nine of the 16 women in the study group. These were tested for viral DNA by in situ hybridisation (table VII). This showed specific hybridisation with more than one probe in most lesions. Only two samples, both showing carcinoma in situ, failed to show specific hybridisation with any of them. Koilocytosis - that is, morphological evidence of human papillomavirus infection ${ }^{11-14}$ was found either in cytological or histological specimens in 11 of 16 cases with cervical intraepithelial neoplasia, including eight of nine with grade III disease. It was also present in the one woman with carcinoma in situ in the control group and in one of the six with mild dysplasia.

There was great variation in the age at which the 16 women with glomerulonephritis had cervical intraepithelial neoplasia diagnosed (figure). The figure shows the course of the disease in each woman, starting with the youngest at the top. She had received immunosuppressive treatment (for systemic lupus erythematosus) before presenting with her kidney lesion. This was followed after three years by the cervical lesion. The next woman presented first with cervical intraepithelial neoplasia, developing glomerulonephritis 12 years later. In summary, the diagnosis of glomerulonephritis preceded that of cervical intraepithelial neoplasia in six women, was made in the same year in one, and came after cervical intraepithelial neoplasia in nine. The interval between the two diagnoses tended to be longer when cervical intraepithelial neoplasia was diagnosed first. Cervical intraepithelial neoplasia occurred in nine of the 16 women with glomerulonephritis who had not received immunosuppressive treatment. When this was used (in seven women) it preceded the diagnosis of glomerulonephritis in four (all with systemic lupus erythematosus), was given on diagnosis in two, and after in one.

Cross checking of the results showed that five of the 
TABLE VI - Number of women with glomerulonephritis showing cervical intraepithelial neoplasia receiving or not receiving immunosuppressive treatment compared with case matched controls

\begin{tabular}{|c|c|c|c|c|c|}
\hline Women & $\begin{array}{l}\text { Treated women with } \\
\text { glomerulonephritis }\end{array}$ & $\begin{array}{c}\text { Case } \\
\text { matched } \\
\text { controls }\end{array}$ & $\begin{array}{l}\text { Untreated women with } \\
\text { glomerulonephritis }\end{array}$ & $\begin{array}{c}\text { Case } \\
\text { matched } \\
\text { controls }\end{array}$ & $\begin{array}{c}\text { All } \\
\text { controls }\end{array}$ \\
\hline $\begin{array}{l}\text { With cervical } \\
\text { intraepithelial neoplasia }\end{array}$ & 5 & 1 & 9 & 6 & 7 \\
\hline $\begin{array}{l}\text { Without cervical } \\
\text { intraepithelial neoplasia }\end{array}$ & 14 & 37 & 53 & 118 & 155 \\
\hline Total & 19 & 38 & 62 & 124 & 162 \\
\hline
\end{tabular}

VII-Results of in situ hybridisation in nine women with cervical intraepithelial neoplasia and glomerulonephritis

\begin{tabular}{|c|c|c|c|c|c|}
\hline \multirow[b]{2}{*}{ Women } & \multirow{2}{*}{$\begin{array}{l}\text { Degree of } \\
\text { cervical } \\
\text { intraepithelial } \\
\text { neoplasia }\end{array}$} & \multicolumn{3}{|c|}{ Hybridisation with probe } & \multirow{2}{*}{$\begin{array}{l}\text { Hybridisation } \\
\text { with } \\
\text { any probe }\end{array}$} \\
\hline & & $6 / 11$ & $16 / 18$ & $31 / 33 / 35$ & \\
\hline 1 & Grade I & + & + & + & + \\
\hline 2 & Grade I & - & + & + & + \\
\hline 3 & Grade I & + & + & + & + \\
\hline 4 & Grade I & - & - & + & + \\
\hline 5 & Grade II & - & + & + & + \\
\hline 6 & Grade II & + & + & + & + \\
\hline 7 & Grade III & - & - & - & $-\star$ \\
\hline 8 & Grade III & - & - & - & $-\star \star$ \\
\hline 9 & Grade III & + & + & - & + \\
\hline \multicolumn{2}{|c|}{$\begin{array}{l}\text { Total No showing specific } \\
\text { hybridisation }\end{array}$} & 4 & 6 & 6 & 7 \\
\hline
\end{tabular}

^Both specimens showed koilocytosis.

six cases with in situ lesions were under 40 years of age, as were eight of the 10 with lesions showing koilocytosis. Furthermore, six of the seven cervical lesions in women receiving immunosuppressive treatment showed koilocytosis, and four of them were carcinoma in situ.

\section{Discussion}

Human papillomavirus infection may in time lead to cervical intraepithelial neoplasia. ${ }^{9}$ Viral types 16,18 , 31,33 , and 35 are particularly associated with the disease. This virus has been shown in tumours in many tissues $^{671516}$ and in normal tissue adjacent to such lesions. ${ }^{17}$ Its association with cervical lesions in immunosuppressed patients is well established. ${ }^{4} 1018$

Our results show that glomerulonephritis and cervical intraepithelial neoplasia may develop in

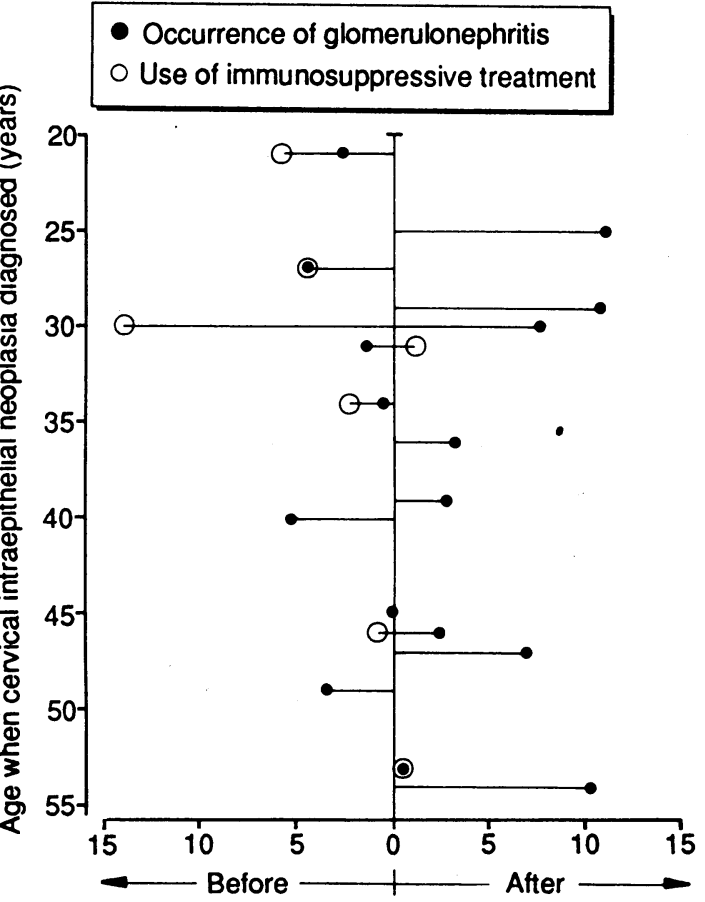

Diagnosis of cervical intraepithelial neoplasia (years) parallel. The renal lesion may present either before or after cervical intraepithelial neoplasia. The cervical intraepithelial neoplasia was of viral origin in most of our cases tested. The presence of more than one human papillomavirus type was common, including both $6 / 11$ and $16 / 18$. In addition, the 81 women with glomerulonephritis had a significantly higher incidence of cervical intraepithelial neoplasia and a greater degree of cervical koilocytosis than those of case matched controls.

Virus infection, in particular human papillomavirus infection, is a well known complication of immunosuppressive treatment. ${ }^{9}$ In keeping with this the cervical lesion developing in women with glomerulonephritis receiving immunosuppressive treatment was more advanced at diagnosis than that in untreated women. Not all of the women with glomerulonephritis who received immunosuppressive treatment showed cervical intraepithelial neoplasia, however, and some had cervical intraepithelial neoplasia without immunosuppression. Furthermore, there was no significant difference in the incidence of cervical intraepithelial neoplasia between those who received and those who did not receive immunosuppressive treatment. Thus there seems to be a primary relation between glomerulonephritis and cervical intraepithelial neoplasia. This may be related to the virus association found in cervical intraepithelial neoplasia. On the basis of our findings cervical intraepithelial neoplasia in women with glomerulonephritis should not be regarded as merely an iatrogenic lesion. All such women should have routine cervical smears, irrespective of their use of immunosuppressive treatment.

This work was supported by the Norwegian Cancer Society.

1 Penn I. Cancer is a complication of severe immunosuppression. Surg Gynecol Obstet 1986;162:603-10.

Penn I. Tumor incidence in human allograft recipients. Transplant Proc 1979;11:1047-51.

3 McVie JG. Immunosuppression. In: Medical immunology. Edinburgh: W J Irvine Teviot, 1979.

4 Halpert R, Fruchter RG, Sedlis A, Butt K, Boyce JG, Sillmann FH. Human papilloma virus and lower genital neoplasia in renal transplant patients.

5 zur Hausen H. Human papillomavirus and their possible role in squamous cell carcinoma. Curr Top Microbiol Immunol 1977;78:1-30.

$6 \mathrm{Pfister} \mathrm{H}$. Biology and biochemistry of papillomaviruses. Rev Physiol Biochem Pharmacol 1984;99:111-81.

7 Gissmann L. Papillomaviruses and their association with cancer in animals an man. Cancer Surv 1984;3:161-81.

8 McCance DJ. Human papillomavirus (HPV) infections in the aetiology of cervical cancer. Cancer Surv 1988;7:499-506.

9 Syriänen KJ. Human papilloma virus (HPV) infections of the female genital tract and their associations with intra-epithelial neoplasia and squamous cell carcinoma. Pathol Annu 1986;21:53-89.

10 Alloub MI, Barr BBB, McLaren KM, Smith IW, Bunney MH, Smart GE. Human papillomavirus infection and cervical intraepithelial neoplasia in women with renal allografts. $B M \mathcal{F}$ 1989;298:153-6.

11 Fletcher S. Histopathology of papillomavirus infection of the cervix uteri: the history, taxonomy, nomenclature and reporting of koilocytosis. $f$ Clin Pathol 1983;36:616-24.

12 Meisels A, Roy M, Fortier M, Morin C, Casas-Cordero M, Shah KV, Turgeon $H$. Human papillomavirus infection of the cervix. The atypical condyloma. Acta Cytol 1985;25:7-16

13 Laverty CR, Russell P, Hills E, Booth N. The significance of noncondylomatous wart virus infection of the cervical transformation zone. A review with discussion of two illustrative cases. Acta Cytol 1978;22:195-201.

14 Hills E, Laverty CR. Electron microscopic detection of papillomavirus particles in selected koilocytotic cells in a routine cervical smear. Acta Cyto 1979;23:53-6.

15 Pfister H, Fuchs PG. Papillomaviruses: particles, genoma organisation and proteins. In: Syriänen K, Gissmann L, Koss LG, eds. Papillomaviruses and human disease. Heidelberg: Springer Verlag, 1987.

16 Kirchner H. Immunobiology of human papillomavirus infection. Prog Med Virol 1986;33:1-41.

17 MacNab JCM, Walkinshaw SA, Cordiner JW, Clements JB. Human papilloma virus in clinically and histologically normal tissue of patients with genital cancer. N Engl F Med 1986;315:1052-8.

18 MacLean AB, Lynn KL, Bailey RR, Swainson CP, Walker RJ. Colposcopic assessment of the lower genital tract in female renal transplant recipients. Clin Nephrol 1986;26:45-7.

19 Schneider V, Kay S, Lee HM. Immunosuppression as a high-risk factor in the development of condyloma acuminatum and squamous neoplasia of the cervix. Acta Cytol 1983;27:220-4.

20 Sillman F, Stanek A, Sedlis A, et al. The relationship between human papillomavirus and lower genital intraepithelial neoplasia in immunosuppressed women. Am f Obstet Gynecol 1984;150:300-8. 